\title{
Pemanfaatan Limbah Kulit Ayam Broiler sebagai Bahan Baku Pembuatan Biodiesel
}

\author{
Isalmi Aziz*, Siti Nurbayti, Lutfi Arqam Dalili \\ Program Studi Kimia Fakultas Sains dan Teknologi Universitas Islam Negeri Syarif Hidayatullah \\ J1. Ir. H. Juanda No.95 Ciputat, Indonesia \\ *Email: isalmikimia@uinjkt.ac.id
}

\begin{abstract}
Abstrak
Telah dilakukan penelitian tentang pembuatan biodiesel dari limbah kulit ayam broiler. Penelitian ini bertujuan untuk menentukan kondisi optimum proses pembuatan biodiesel dan menentukan karakteristik biodiesel yang dihasilkan. Limbah kulit ayam broiler diekstrak lemaknya dengan cara pemanasan. Lemak direaksikan dengan campuran katalis $\mathrm{KOH}$ dan metanol sehingga menghasilkan biodiesel. Optimasi proses dilakukan dengan memvariasikan waktu reaksi, suhu dan konsentrasi katalis. Pada penelitian ini didapatkan kondisi optimum pada :waktu reaksi 60 menit, suhu $60^{\circ} \mathrm{C}$ dan konsentrasi katalis $\mathrm{KOH} 1 \%$ dengan rendemen biodiesel $88 \%$. Karakteristik biodiesel adalah specific gravity $\left(60 / 60^{\circ} \mathrm{F}\right) 0.8904$, densitas $\left(40^{\circ} \mathrm{C}\right) 0.87 \mathrm{~g} / \mathrm{mL}$, titik nyala $212.5^{\circ} \mathrm{C}$, titik tuang $9^{\circ} \mathrm{C}$, kandungan air $1.6 \%$, warna 1 dan CCR $0.739 \%$. Senyawa kimia yang dominan adalah :metil oleat $34.6 \%$ dan metil palmitat $17.16 \%$.
\end{abstract}

Kata kunci : Biodiesel, limbah kulit ayam broiler, transesterifikasi, metil oleat, metil palmitat

\begin{abstract}
The research on biodiesel production has been conducted from waste broiler chicken skin. This study was to determine the optimum process conditions determine the characteristics of biodiesel and biodiesel produced. Waste broiler skin fat extracted by means of heating. Fat is reacted with a mixture of $\mathrm{KOH}$ catalyst and methanol to produce biodiesel. Optimization of the process carried out by varying the reaction time, temperature and catalyst concentration. In this study, the optimum conditions: reaction time $60 \mathrm{~min}$, temperature $60^{\circ} \mathrm{C}$ and the concentration of $1 \% \mathrm{KOH}$ catalyst with a yield of $88 \%$ biodiesel. The characteristics of biodiesel as follows: specific gravity $\left(60 / 60^{\circ} \mathrm{F}\right)$ 0.8904 , density $\left(40^{\circ} \mathrm{C}\right) 0.87 \mathrm{~g} / \mathrm{mL}, 212.5^{\circ} \mathrm{C}$ flash point, pour point $9^{\circ} \mathrm{C}, 1.6 \%$ moisture content, color 1 and CCR $0.739 \%$. The dominant chemical compounds are: methyl oleic $34.6 \%$ and $17.16 \%$ methyl palmitate.
\end{abstract}

Keywords: Biodiesel, waste of broiler chicken skin, transesterification, methyl oleic, methyl palmitate

\section{PENDAHULUAN}

Biodiesel merupakan bahan yang
sangat potensial digunakan untuk
menggantikan bahan bakar diesel. Hal ini
disebabkan karena bahan bakunya yang berasal
dari minyak nabati/hewani yang dapat
diperbaharui, dapat dihasilkan secara periodik
dan mudah diperoleh. Selain itu harganya
relatif stabil dan produksinya mudah
disesuaikan dengan kebutuhan. Dari segi
lingkungan biodiesel juga merupakan bahan
yang biodegradability dan emisi polutannya

relatif kecil, karena kadar hidrokarbon yang tidak terbakar dan CO-nya lebih rendah. Biodiesel juga tidak mengandung belerang sehingga dapat mengurangi kerusakan lingkungan yang diakibatkan oleh hujan asam (rain acid) (Suwarso 2008).

Biodiesel dari minyak nabati sudah banyak dikembangkan tetapi biodiesel dari lemak hewani masih sedikit. Salah satu sumber lemak hewani yang dapat dijadikan sebagai bahan baku biodiesel adalah limbah kulit ayam broiler. Kulit ayam broiler belum banyak dimanfaatkan oleh masyarakat dan sering 
dibuang sebagai limbah potongan hewan.Pemanfaatan limbah kulit ayam broiler sebagai bahan baku biodiesel dapat menanggulangi pencemaran lingkungan sehingga bernilai ekonomis. Berdasarkan penelitian tentang analisa karakterisasi lemak hewani, bahwa kadar lemak ayam sekitar \pm 10\% (Hermanto dan Muawanah 2008).

Secara umum proses pembuatan biodiesel dapat dilakukan dengan reaksi transesterifikasi.Transesterifikasi adalah suatu reaksi yang menghasilkan ester dimana salah satu pereaksinya juga merupakan senyawa ester. Jadi disini terjadi pemecahan senyawa trigliserida dan migrasi gugus alkil antara senyawa ester (Aziz 2007).Ester yang dihasilkan dari reaksi transesterifikasi ini disebut biodiesel.

Reaksitransesterifikasi merupakan reaksi bolak balik yang relatif lambat.Untuk mempercepat jalannya reaksi dan meningkatkan hasil, proses dilakukan dengan pengadukan yang baik, penambahan katalis dan pemberian reaktan berlebih agar reaksi bergeser ke kanan.Secara umum faktor-faktor yang mempengaruhi reaksi transesterifikasi adalah pengadukan, suhu, katalis, perbandingan pereaksi dan waktu reaksi.

Penelitian ini akanmenentukan kondisi optimum proses pembuatan biodiesel dengan bahan baku limbah kulit ayam broiler dan metanol dengan katalis KOH. Pemilihan metanol sebagai alkohol didasarkan pada reaktifitasnya yang tinggi, tidak mudah mengikat air, ekonomis, kemudahan dalam memperoleh kembali (recovery) dan mendaur ulang (recycle).Parameter yang di optimasi adalah waktu reaksi, suhu dan konsentrasi katalis.Biodiesel yang dihasilkan ditentukan komposisi kimianya menggunakan GCMS.

\section{METODE PENELITIAN}

\section{Alat dan Bahan}

Alat yang digunakan dalam penelitian ini adalah GCMS, labu leher tiga, pengaduk, termometer dan kondensor.Bahan yang digunakan adalah kulit ayam broiler, akuades, $\mathrm{KOH}$ dan metanol

\section{Ekstraksi Lemak dari Kulit Ayam Broiler (Hermanto dan Muawanah 2008)}

Kulit ayam broiler dicuci, diiris kecilkecil dan dimasukkan ke dalam beaker glass. Selanjutnya sampel dimasukkan ke dalam oven yang sudah diatur suhunya $\left(75^{\circ} \mathrm{C}\right)$, dibiarkan selama 6 jam hingga jaringan lemaknya mencair. Lemak padat yang sudah mencair dipisahkan dan dimasukkan ke dalam corong pisah. $\mathrm{Na}_{2} \mathrm{SO}_{4}$ anhidrat ditambahkan ke dalam lemak yang sudah mencair untuk menyerap kandungan airnya.

\section{Penentuan Kadar Air Lemak Kulit Ayam Broiler}

Cawan porselin kering ditimbang $\left(\mathrm{W}_{1}\right)$ lalu dimasukan lemak sebanyak $5 \mathrm{~g}$ dan ditimbang $\left(\mathrm{W}_{2}\right)$. Cawan yg berisi sample diasukan kedalam oven selama 4 jam pd suhu $110{ }^{\circ} \mathrm{C}$. Setelah itu masukan kedalam desikator dan ditimbang $\left(\mathrm{W}_{3}\right)$.

$\operatorname{Kadarair}(\%)=\frac{W_{2}-W_{3}}{W_{3}-W_{1}} \times 100$

\section{Penentuan Asam Lemak Bebas (FFA) Lemak Kulit Ayam Broiler}

Lemak sebanyak 5 gram dimasukkan kedalam elenmeyer kemudian ditambahkan 50 $\mathrm{ml}$ alkohol.Campuran dipanaskan selama 10 menit sampai asam lemak larut. Setelah itu didinginkan dan dititrasi dengan $\mathrm{KOH} 0.1 \mathrm{~N}$ dengan indikator $\mathrm{pp}$.

$$
F F A=\frac{\text { Volum } \mathrm{KOH}}{\text { Bera t minyak }} \times \mathrm{N} . \mathrm{KOH}
$$

\section{Pembuatan Biodiesel}

Lemak kulit ayam Broiler sebanyak 40 $\mathrm{mL}$ dipanaskan pada suhu $60{ }^{\circ} \mathrm{C} . \mathrm{KOH}(1 \%$ berat minyak) dilarutkan dalam $10 \mathrm{~mL}$ metanol sehingga membentuk kalium metoksida.Larutan ini dicampurkan ke dalam minyak yang sudah dipanaskan.Reaksi di jalankan selama 15 menit.Produk yang 
dihasilkan di sentrifuse sehingga dihasilkan 2 lapisan.Lapisan atas adalah biodiesel dan lapisan bawah adalah crude glyserol.Biodiesel yang dihasilkan dipanaskan pada suhu $70{ }^{\circ} \mathrm{C}$ dan ditimbang beratnya. Rendemen biodiesel yang dihasilkan dihitung dengan rumus :

Rendemen $(\%)=\frac{\text { Berat biodiesel }(g)}{\text { Berat minyak }(g)} 100 \%$

Reaksi juga dilakukan dengan variasi konsentrasi katalis $\mathrm{KOH} 0.5 \%$; $1.5 \%$ dan $2 \%$; suhu $30,40,50$ dan $70^{\circ} \mathrm{C}$ dan waktu reaksi 15 , 30, 45, 90 menit hingga diperoleh kondisi optimum pembuatan biodiesel.

Biodiesel yang dihasilkan pada kondisi optimum selanjutnya dianalisa karakteristiknya meliputi spesific gravity $\left(60 / 60^{\circ} \mathrm{F}\right)$, densitas $\left(40^{\circ} \mathrm{C}\right)$, titik nyala, titik tuang, kandungan air, CCR dan komposisi senyawa kimianya dengan GCMS

\section{HASIL DAN PEMBAHASAN}

\section{Sifat Fisik dan Kimia Lemak dari Kulit Ayam Broiler}

Lemak dari kulit ayam broiler yang diperoleh dari pemanasan dalam oven pada suhu $75^{\circ} \mathrm{C}$ dianalisa sifat fisik dan kimianya (Tabel 1).Lemak dari kulit ayam broiler yang digunakan dalam penelitian ini mengandung kadar air sebesar $0.2 \%$. Kadar air yang terkandung dalam minyak kulit ayam broiler kurang dari $1 \%$ sehingga tidak perlu ada perlakuan untuk menghilangkan kadar air. Menurut Ramadhansyah et al. (2009) syaratmaksimal kadar air pada minyak adalah 1\%. Jika kadar air lebih dari $1 \%$ maka perlu adanya perlakuan lebih lanjut untuk menghilangkan kadar air yang terkandung dalam minyak.Kadar air yang tinggi (lebih dari $1 \%$ ) dapat mengakibatkan reaksi samping yaitu reaksi hidrolisis antara trigliserida dengan air yang menghasilkan asam lemak bebas yang dapat mengganggu reaksi pembentukan biodiesel.
Tabel 1 Sifat fisik dan kimia lemak dari kulit ayam broiler

\begin{tabular}{clcc}
\hline No & Sifat Fisik Kimia & Satuan & Nilai \\
\hline $\mathbf{1}$ & Kadar air & $\%$ & 0.2 \\
$\mathbf{2}$ & Asam lemak bebas & $\%$ & 1 \\
\hline
\end{tabular}

Kadar asam lemak bebas (ALB) yang terkandung dalam minyak kulit ayam broiler adalah 1\%.Nilai ini lebih kecil dari batas yang ditetapkan yaitu maksimal adalah 2\%.Pembuatan biodiesel langsung menggunakan reaksi transesterifikasidapat dilakukan jika kandungan asam lemak bebas (ALB) dalam suatu minyak $\leq 2 \%$, sedangkan jika minyak mengandung asam lemak bebas (ALB) tinggi ( $\geq 2 \%$ ), maka perlu dilakukan pretreatment yaitu reaksi esterifikasi untuk menurunkan asam lemak bebas (ALB) menjadi $\leq 2 \%$ dengan cara mengubah asam lemak bebas menjadi metil ester dengan bantuan katalis asam (Ramadhansyah et al. 2009).

Menurut Samios et al. (2009) pada pembuatan metil ester dengan cara transesterifikasi, apabila bahan baku mempunyai asam lemak bebas (ALB) tinggi maka akan dapat menyebabkan terjadi blocking yaitu metanol yang seharusnya bereaksi dengan trigliserida terhalang oleh pembentukan sabun. Sabun terbentuk ketika katalis basa kuat bereaksi dengan asam lemak bebas (ALB), sehingga menyebabkan konsumsi katalis menjadi besar dan produk metil ester tidak maksimal.

Pada dasarnya tinggi atau rendahnya kandungan asam lemak bebas tergantung oleh kadar air dalam minyak tersebut. Semakin tinggi nilai kadar air, semakin tinggi pula nilai kadar asam lemak bebas dari minyak dan akan menyebabkan rendemen biodiesel menjadi turun. Hal ini mungkin disebabkan karena dalam proses pengolahan lemak tersebut terjadi proses oksidasi yang sangat tinggi. 


\section{Pengaruh Waktu Reaksi terhadap Rendemen Biodiesel}

Pengaruh waktu reaksi dipelajari dari 15-90 menit. Parameter lain dibuat konstanyaitu : suhu $60^{\circ} \mathrm{C}$, konsentrasi katalis $\mathrm{KOH}$ ( $1 \%$ berat minyak) dan perbandingan reaktan 4:1 (volum) (minyak ayam broiler : metanol) dengan kecepatan putaran $500 \mathrm{rpm}$.

Gambar 2 memperlihatkan bahwa semakin lama waktu reaksi, rendemen biodiesel semakin besar. Hal ini disebabkan karena lamanya waktu reaksi memberikan kesempatan yang besar bagi molekul-molekul reaktan untuk saling bertumbukan dan bereaksi. Pada 15 menit pertama rendemen sudah mencapai $84 \%$. Ini menandakan bahwa reaksi transesterifikasi adalah reaksi yang berlangsung dengan cepat. Pada menit ke 60 rendemen yang dihasilkan mencapai $88 \%$. Memasuki menit ke 90 terjadi penurunan rendemen hingga $86 \%$. Hal ini mungkin disebabkan lamanya reaksi menyebabkan terurainya kalium metoksida menjadi kalium hidroksida dan metanol, sehingga $\mathrm{KOH}$ bereaksi dengan minyak membentuk sabun. Dari sini dapat disimpulkan bahwa waktu reaksi optimum adalah 60 menit.

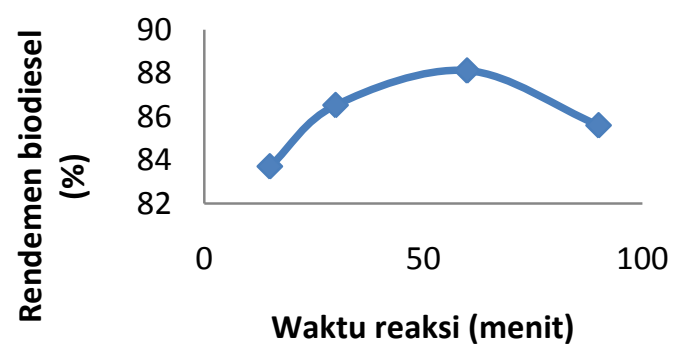

Gambar 2 Pengaruh waktu reaksi terhadap rendemen biodiesel (suhu $60^{\circ} \mathrm{C}$, katalis $\mathrm{KOH} 1 \%$, kecepatan putaran $500 \mathrm{rpm})$

\section{Pengaruh Suhu Reaksi terhadap Rendemen Biodiesel}

Parameter kedua yang diuji adalah pengaruh suhu reaksi.Setelah parameter waktu reaksi optimum diperoleh, maka dapat digunakan sebagai variabel yang konstan yaitu waktu reaksi 60 menit dan konsentrasi katalis $1 \%$.

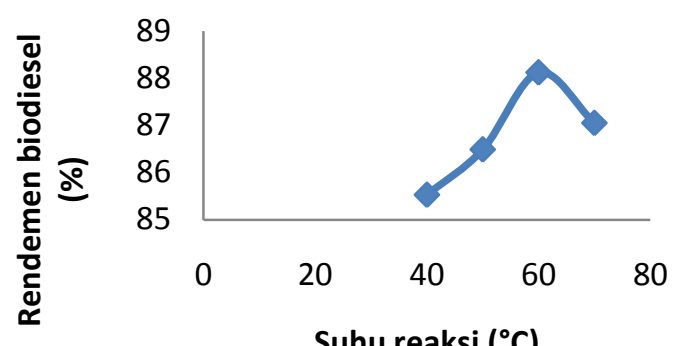

Gambar 3 Pengaruh suhu reaksi terhadap rendemen biodiesel (waktu reaksi 60 menit, katalis $\mathrm{KOH} 1 \%$, kecepatan putaran $500 \mathrm{rpm}$ )

Gambar 3menunjukkan bahwa rendemen biodiesel meningkat seiring dengan naiknya suhu reaksi dari suhu $40^{\circ} \mathrm{C}$ sampai $60^{\circ} \mathrm{C}$.Pada suhu $60^{\circ} \mathrm{C}$ rendemen biodiesel sebesar $88 \%$.Hal ini terjadi karena dengan naiknya suhu, maka tumbukan antar partikel semakin besar, sehingga reaksi berjalan semakin cepat dan konstanta reaksi semakin besar.

Namun ketika suhu reaksi dinaikkan lagi menjadi $70^{\circ} \mathrm{C}$, rendemen biodiesel turun sebesar $87 \%$.Hal ini disebabkan karena titik didih metanol adalah suhu $64.7^{\circ} \mathrm{C}$, maka pada suhu tersebut $\left(70^{\circ} \mathrm{C}\right)$ sebagian metanol akan berubah fase menjadi fase uap dan lolos dari sistem reaksi, maka kontak antara metanol dan minyak maupun katalis akan berkurang, sehingga menyebabkan rendemen biodiesel menurun.

\section{Pengaruh Konsentrasi Katalis terhadap Rendemen Biodiesel}

Setelah diperoleh data optimum untuk waktu reaksi 60 menit dan suhu $60^{\circ} \mathrm{C}$, parameter selanjutnya yang divariasikan adalah pengaruh konsentrasi katalis. 


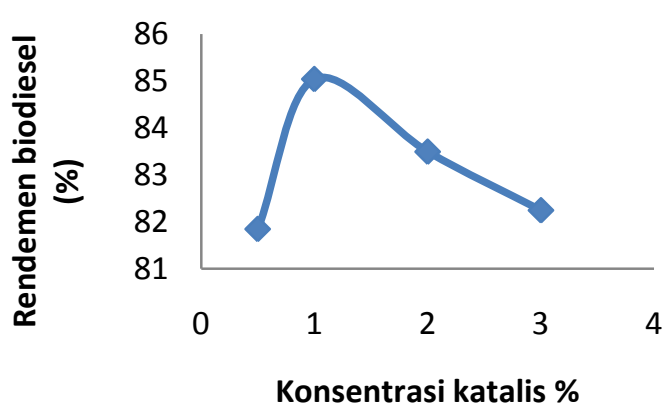

Gambar 4 Pengaruh konsentrasi katalis terhadap rendemen biodiesel

Konsentrasi katalis $\mathrm{KOH} \quad 0.5 \%$ menghasilkan rendemen biodiesel sebesar $81.84 \%$ (Gambar 4).Ketika konsentrasi katalis dinaikkan menjadi $1 \%$, terjadi kenaikan rendemen biodiesel sebesar $85.04 \%$.Pada konsentrasi tersebut (1\%) reaksi dapat dikatakan telah berjalan optimal yang terlihat pada gambar 4 terjadi peningkatan nilai rendemen biodiesel yang cukup tinggi pada konsentrasi katalis 1\%. Hal ini disebabkan semakin bertambahnya konsentrasi katalis maka semakin tinggi rendemen biodiesel yang dihasilkan, karena semakin banyak katalis akan menurunkan energi aktivasi sehingga konstanta reaksi semakin cepat. Akan tetapi, pada saat konsentrasi $2 \%$ sampai $3 \%$ mulai terjadi penurunan nilai rendemen yang yang cukup drastis.Hal tersebut disebabkan adanya reaksi samping antara $\mathrm{KOH}$ dengan minyak yang menghasilkan reaksi penyabunan.Dengan adanya $\mathrm{KOH}$ berlebih tersebut dapat menghalangi reaksi antara minyak dengan metanol yang menghasilkan kecepatan reaksi biodiesel menurun juga $\mathrm{KOH}$ yang seharusnya berfungsi sebagai katalis menjadi reaktan ikut bereaksi dengan minyak yang menhasilkan produk, sehingga efektivitas katalis semakin menurun.

Marnoto dan Efendi (2011) mendapatkan kondisi optimum pembuatan biodiesel dari lemak ayam broiler dengan menggunakan spiritus dan katalis kapur tohor pada waktu 90 menit, suhu $70^{\circ} \mathrm{C}$, konsentrasi katalis 5\%-6\% berat minyak dengan konversi sekitar 0.9105-0.9403.

\section{Senyawa Penyusun Biodiesel}

Untuk menentukan komposisi senyawa kimia pada biodiesel yang dihasilkan, maka dilakukan uji dengan GC-MS. Hasil spektrum analisa GC-MS dari biodiesel adalah sebagai berikut.

Abundance

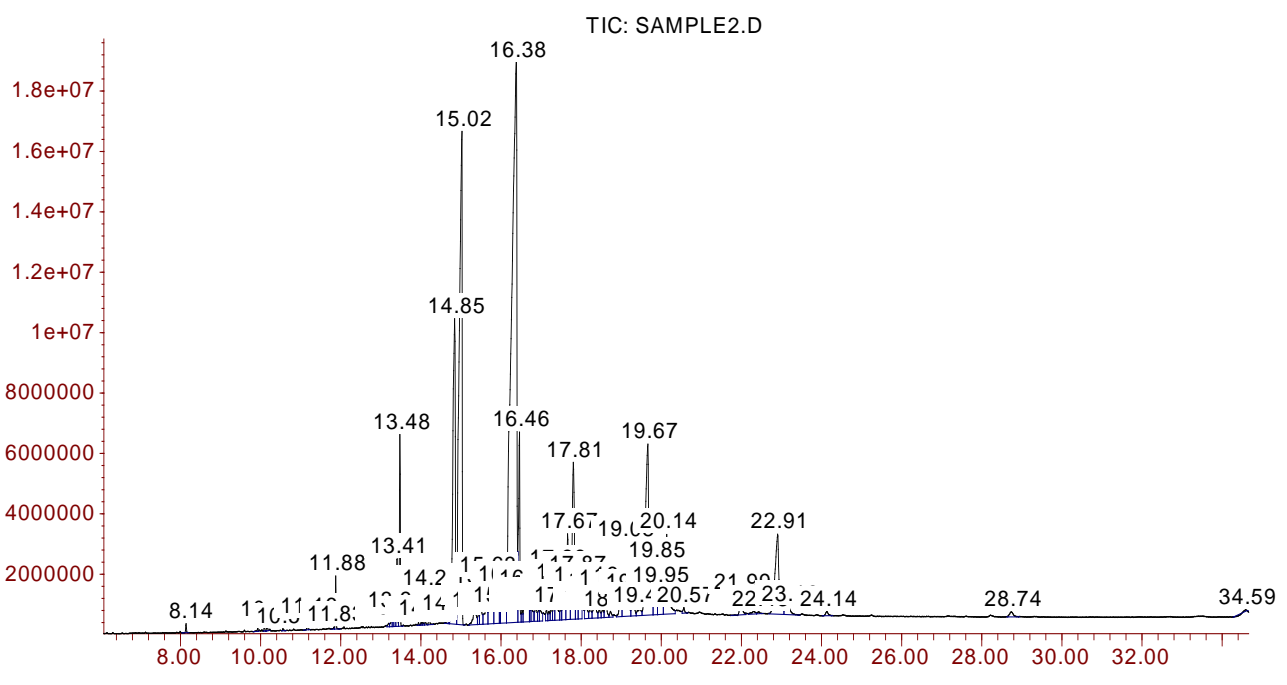

Gambar 5 Kromatogram GC-MS biodiesel 
Tabel 2 Nama-nama senyawa kimia biodiesel

\begin{tabular}{|c|c|c|c|c|}
\hline Peak & $\begin{array}{l}\text { Waktu } \\
\text { retensi }\end{array}$ & $\begin{array}{c}\text { Luas } \\
\text { area } \% \\
\end{array}$ & Nama senyawa & Rumus molekul \\
\hline 1 & 8.14 & 0.09 & Octanoic acid, methyl ester & $\mathrm{C}_{9} \mathrm{H}_{18} \mathrm{O}_{2}$ \\
\hline 2 & 10.1 & 0.12 & Decanoic acid, methyl ester & $\mathrm{C}_{11} \mathrm{H}_{22} \mathrm{O}_{2}$ \\
\hline 3 & 10.16 & 0.09 & trans,trans-2,4-decadienal & $\mathrm{C}_{10} \mathrm{H}_{16} \mathrm{O}$ \\
\hline 4 & 11.16 & 0.14 & Nonanoic acid, 9-oxo-, methyl ester & $\mathrm{C}_{10} \mathrm{H}_{18} \mathrm{O}_{3}$ \\
\hline 5 & 11.17 & 0.13 & Methyl trans-3-formyloxycyclopentaneacetate & $\mathrm{C}_{9} \mathrm{H}_{14} \mathrm{O}_{4}$ \\
\hline 6 & 11.87 & 0.53 & Dodecanoic acid, methyl ester (Methyl laurate) & $\mathrm{C}_{13} \mathrm{H}_{26} \mathrm{O}_{2}$ \\
\hline 7 & 13.27 & 0.19 & 2-methyl-Z,Z-3, 13-octadecadienol & $\mathrm{C}_{19} \mathrm{H}_{36} \mathrm{O}$ \\
\hline 8 & 13.31 & 0.14 & 1,7-Dodecadiene & $\mathrm{C}_{12} \mathrm{H}_{22}$ \\
\hline 9 & 13.41 & 0.78 & Methyl E-11-tetradecenoate & $\mathrm{C}_{15} \mathrm{H}_{28} \mathrm{O}_{2}$ \\
\hline 10 & 13.48 & 2.05 & Tetradecanoic acid, methyl ester (methyl myristate) & $\mathrm{C}_{15} \mathrm{H}_{30} \mathrm{O}_{2}$ \\
\hline 11 & 14.21 & 0.33 & Pentadecanoic acid, methyl ester & $\mathrm{C}_{16} \mathrm{H}_{32} \mathrm{O}_{2}$ \\
\hline 12 & 14.66 & 0.23 & 4,7,10-Hexadecatrienoic acid, methyl ester & $\mathrm{C}_{17} \mathrm{H}_{28} \mathrm{O}_{2}$ \\
\hline 13 & 14.7 & 0.11 & 9,12-Octadecadienoic acid $(Z, Z)$ (Linoleic acid) & $\mathrm{C}_{18} \mathrm{H}_{32} \mathrm{O}_{2}$ \\
\hline 14 & 14.84 & 8.89 & $\begin{array}{c}\text { 9-Hexadecenoic acid, methyl ester (methyl } \\
\text { palmitoleate) }\end{array}$ & $\mathrm{C}_{17} \mathrm{H}_{32} \mathrm{O}_{2}$ \\
\hline 15 & 15.02 & 17.16 & Hexadecanoic acid, methyl ester (methyl palmitate) & $\mathrm{C}_{17} \mathrm{H}_{34} \mathrm{O}_{2}$ \\
\hline 16 & 15.34 & 0.35 & n-Hexadecanoic acid (palmitic acid) & $\mathrm{C}_{16} \mathrm{H}_{32} \mathrm{O}_{2}$ \\
\hline 17 & 15.63 & 0.45 & Hexadecanoic acid, 14-methyl-, methyl ester & $\mathrm{C}_{18} \mathrm{H}_{36} \mathrm{O}_{2}$ \\
\hline 18 & 15.77 & 0.07 & Tetradecanoic acid, (Myristic acid) & $\mathrm{C}_{14} \mathrm{H}_{28} \mathrm{O}_{2}$ \\
\hline 19 & 16.09 & 0.59 & 6,9,12-Octadecatrienoic acid, methyl ester & $\mathrm{C}_{19} \mathrm{H}_{32} \mathrm{O}_{2}$ \\
\hline 20 & 16.39 & 34.6 & 9-Octadecenoic acid (Z), methyl ester (methyl oleate) & $\mathrm{C}_{19} \mathrm{H}_{36} \mathrm{O}_{2}$ \\
\hline 21 & 16.46 & 2.69 & Octadecanoic acid, methyl ester (methyl stearate) & $\mathrm{C}_{19} \mathrm{H}_{38} \mathrm{O}_{2}$ \\
\hline 22 & 16.62 & 0.72 & 9-Octadecenoic acid (Z)- (Oleic acid) & $\mathrm{C}_{18} \mathrm{H}_{34} \mathrm{O}_{2}$ \\
\hline 23 & 16.87 & 0.17 & $\begin{array}{c}\text { 9,12-Octadecadienoic acid, methyl ester (methyl } \\
\text { linoleate) }\end{array}$ & $\mathrm{C}_{19} \mathrm{H}_{34} \mathrm{O}_{2}$ \\
\hline 24 & 17.26 & 0.11 & 9,17-Octadecadienal, (Z)- & $\mathrm{C}_{18} \mathrm{H}_{32} \mathrm{O}$ \\
\hline 25 & 17.32 & 0.2 & $\begin{array}{c}\text { Cyclohexane, } 1-(1,5-\text { dimethylhexyl)-4-(4- } \\
\text { methylpentyl) }\end{array}$ & $\mathrm{C}_{20} \mathrm{H}_{40}$ \\
\hline 26 & 17.55 & 0.6 & $\begin{array}{c}5,8,11,14 \text {-Eicosatetraenoic acid, methyl ester (methyl } \\
\text { arachidonate) }\end{array}$ & $\mathrm{C}_{21} \mathrm{H}_{34} \mathrm{O}_{2}$ \\
\hline 27 & 17.81 & 3.9 & Palmitic acid chloride & $\mathrm{C}_{16} \mathrm{H}_{31} \mathrm{ClO}$ \\
\hline 28 & 17.87 & 0.68 & Z-8-methyl-9-tetradecenoic acid & $\mathrm{C}_{15} \mathrm{H}_{28} \mathrm{O}_{2}$ \\
\hline 29 & 17.99 & 0.62 & $\begin{array}{c}\text { Eicosanoic acid, methyl ester (Arachidic acid methyl } \\
\text { ester) }\end{array}$ & $\mathrm{C}_{21} \mathrm{H}_{42} \mathrm{O}_{2}$ \\
\hline 30 & 18.35 & 0.57 & Cyclopropaneoctanoic acid, 2-octyl-,methyl ester & $\mathrm{C}_{20} \mathrm{H}_{38} \mathrm{O}_{2}$ \\
\hline 31 & 18.99 & 0.62 & Dodecane,1-cyclopentyl-4-(3-cyclopentylpropyl) & $\mathrm{C}_{25} \mathrm{H}_{48}$ \\
\hline 32 & 19.67 & 6.78 & 9-Octadecenal, $(Z)$ & $\mathrm{C}_{18} \mathrm{H}_{34} \mathrm{O}$ \\
\hline
\end{tabular}




\begin{tabular}{|c|c|c|c|c|}
\hline 33 & 19.85 & 1.24 & Cyclononanone & $\mathrm{C}_{10} \mathrm{H}_{15} \mathrm{O}_{30}$ \\
\hline 34 & 19.95 & 1.01 & Z,Z-10, 12-Hexadecadienal & $\mathrm{C}_{16} \mathrm{H}_{28} \mathrm{O}$ \\
\hline 35 & 20.14 & 2.48 & $\begin{array}{l}\text { Hexadecanoic acid, 2-hydroxy-1- } \\
\text { (hydroxymethyl)ethyl ester }\end{array}$ & $\mathrm{C}_{19} \mathrm{H}_{38} \mathrm{O}_{4}$ \\
\hline 36 & 21.99 & 0.46 & $p$-(2-butyl)styrene & $\mathrm{C}_{12} \mathrm{H}_{16}$ \\
\hline 37 & 22.91 & 3.89 & 9-Octadecenoic acid (Z)-,2,3-dihydroxypropyl ester & $\mathrm{C}_{21} \mathrm{H}_{40} \mathrm{O}_{4}$ \\
\hline
\end{tabular}

Berdasarkan tabel di atas terdapat 37 senyawa yang ada dalam biodiesel.Senyawa yang dihasilkan berkisar dari atom C9C25.Jumlah atom $\mathrm{C}$ ini mendekati jumlah atom $\mathrm{C}$ untuk bahan bakar solar dan minyak diesel.

Dilihat dari jenis senyawa yang ada cukup beragam, ada golongan hidrokarbon, aldehid, karboksilat dan ester.Senyawa yang dominan adalah golongan ester.Kandungan metil ester yang paling besar adalah metil oleat (34.60\%) dan metil palmitat (17.16\%).

\section{Densitas dan Spesific Gravity}

Densitas biodiesel yang dihasilkan pada penelitian ini adalah $0.87 \mathrm{~g} / \mathrm{mL}$ seperti yang terlihat pada Tabel 3.Nilai ini memenuhi syarat SNI biodiesel (0.85-0.89).Jika dibandingkan dengan hasil penelitian Maryoto dan Efendi(2011), nilai densitas biodiesel penelitian ini lebih besar.Maryoto dan Efendi(2011) mendapatkan densitas sebesar $0.85 \mathrm{~g} / \mathrm{mL}$.Spesific gravity yang dihasilkan juga memenuhi standar bahan bakar solar dan minyak diesel.

Tabel 3 Karakteristik biodiesel dari kulit ayam broiler

\begin{tabular}{|c|c|c|c|c|c|c|}
\hline No. & Jenis Pemeriksaan & Satuan & $\begin{array}{c}\text { Hasil } \\
\text { Pemeriksaan }\end{array}$ & SNI Biodiesel & Solar & $\begin{array}{c}\text { minyak } \\
\text { diesel }\end{array}$ \\
\hline 1 & $\begin{array}{l}\text { Specific } \quad \text { Gravity at } \\
60 / 60^{\circ} \mathrm{F}\end{array}$ & - & 0.8904 & - & $\begin{array}{l}0.820- \\
0.870\end{array}$ & $\begin{array}{l}0.840- \\
0.920\end{array}$ \\
\hline 2 & $\begin{array}{l}\text { Viskositas kinematik, } \\
40{ }^{\circ} \mathrm{C}\end{array}$ & $\mathrm{mm}^{2} / \mathrm{s}$ & 24.72 & $2.3-2.6$ & $1.6-5.8$ & \\
\hline 3 & Titik nyala. & ${ }^{0} \mathrm{C}$ & 212.5 & Min. 100 & $\min .150$ & $\min .150$ \\
\hline 4 & Densitas $\left(40^{\circ} \mathrm{C}\right)$ & $\mathrm{g} / \mathrm{mL}$ & 0.87 & $0.85-0.89$ & - & - \\
\hline 5 & Titik tuang & ${ }^{0} \mathrm{C}$ & 9 & - & mak.65 & mak.65 \\
\hline 6 & Kandungan air & $\%$ Vol. & 1.6 & 0.05 & mak.0.05 & mak.0.25 \\
\hline 7 & $\begin{array}{l}\text { Conradson } \\
\text { Residue }\end{array}$ & $\% \mathrm{wt}$ & 0.739 & - & mak.0.1 & mak.1.0 \\
\hline 8 & Warna & & 1 & - & Maks.3 & Maks.6 \\
\hline
\end{tabular}

\section{Viskositas Kinematik}

Viskositas kinematik biodiesel seperti yang tercantum dalam tabel 3 sebesar 24.72cSt. Nilai ini diluar standar SNI biodiesel yang ditetapkan pemerintah yaitu 2.3-6 cSt. Hal ini disebabkan belum sempurnanya reaksi transesterifikasi sehingga masih banyak lemak (trigliserida) yang terikut bersama biodiesel.Viskositas mempunyai peranan yang sangat penting dalam proses penginjeksian bahan bakar. Viskositas yang terlalu rendah dapat menyebabkan kebocoran pada pompa injeksi bahan bakar dan kalau terlalu tinggi dapat mempengaruhi kerja cepat alat injeksi dan mempersulit pengabutan bahan bakar (Hardjono 2001).

\section{Kadar Air}

Nilai kadar air dari biodiesel pada penelitian ini sebesar 1.6\%. Berdasarkan 
standar SNI kadar air maksimum untuk SNI yakni sebesar $0.05 \%$. Maka kadar air biodiesel ini belum memenuhi standar. Kadar air yang tinggi mungkin disebabkan belum sempurnanya pemisahan biodiesel dengan air pada saat proses pemurnian (pencucian dengan air). Kadar air yang tinggi dapat membentuk kristal-kristal parafin pada suhu dingin yang bisa menyumbat aliran bahan bakar.

\section{Titik Nyala}

Titik nyala yang didapatkan sebesar $212.5{ }^{\circ}$ C.Nilai ini memenuhi standar bahan bakar solar dan SNI biodiesel (minimal 100 ${ }^{\circ} \mathrm{C}$ ). Besarnya titik nyala yang didapatkan menunjukan bahwa biodiesel ini aman untuk digunakan.

\section{Titik Tuang}

Titik tuang yang diperoleh sebesar $9^{\circ} \mathrm{C}$ atau $48.2{ }^{\circ} \mathrm{F}$.Standar solar mensyaratkan bahwa titik tuang maksimal $65{ }^{\circ} \mathrm{F}$. Berarti biodiesel yang diperoleh dari penelitian ini memenuhi standar bahan bakar solar.

\section{SIMPULAN}

Kondisi optimum pembuatan biodiesel dari limbah kulit ayam broiler di dapat pada : waktu 60 menit, suhu $60^{\circ} \mathrm{C}$ dan konsntrasi katalis $\mathrm{KOH} \quad 1 \%$ dengan rendemen $88 \%$.Karakteristik biodiesel yang memenuhi SNI Biodiesel adalah densitas, titik nyala, titik tuang dan warna.

Kandungan senyawa kimia yang terbesar adalah metil oleat $(34.60 \%)$ dan metil palmitat (17.16\%).

\section{Ucapan Terimakasih}

Pada kesempatan ini penulis mengucapkan terimakasih kepada Lembaga Penelitian UIN Syarif Hidayatullah Jakarta yang telah mendanai penelitian ini.

\section{Daftar Pustaka}

Aziz I. 2007.Kinetika reaksi transesterifikasi minyak goreng bekas.Jurnal Valensi. 1(1): 19-23

Hardjono A. 2001. Teknologi Minyak Bumi.Yogyakarta (ID): Gadjah Mada University Press.

Hermanto S, Muawanah A. 2008. Profil dan karakteristik lemak hewani (ayam, sapi dan babi) hasil analisa FTIR dan GCMS. Jurnal Valensi. Vol 1. No. 3, 102-109.

Marnoto T, Efendi A. 2011.Biodiesel Dari Lemak Hewani (Ayam Broiler) Dengan Katalis Kapur Tohor.Prosiding Seminar Nasional Teknik Kimia Kejuangan. Yogyakarta (ID): E.10.1-E.10.5.

Ramadhansyah, Sundaryono A, Budiyanto. 2009. Perengkahan katalitik metal ester limbah cair pengolahan $\mathrm{CPO}$ menjadi biofuel dengan katalis zeolite. [Skripsi]. Bengkulu (ID): P.Kimia-JPMIPA FKIP Universitas Bengkulu.

Samios D, Pedrotti F, Nicolau A, Reiznautt QB, Martini DD, Dalcin FD. 2009. Transesterification double step proccesTDSP for biodiesel preparation from fatty acids triglycerides.Fuel Processing Technology.90: 599-605.

Suwarsono WP, Gani IY, Kusyanto. 2008. Sintesis biodiesel dari minyak biji ketapang yang berasal dari pohon ketapang yang tumbuh di kampus UI Depok. Jurnal Valensi. 1(2): 44-52. 